\title{
POST-HARBOUR AREAS - NEW URBAN SPACE
}

\author{
Urszula NOWACKA-REJZNER ${ }^{1}$ \\ Cracow University of Technology, \\ Faculty of Architecture, Kraków, Poland
}

\begin{abstract}
In the article on selected examples one illustrated the different solutions for shaping post-harbour areas. One highlighted the complexity and longevity of activities conducted in these areas, which include both: the modernization of building structures, shaping of new functional and spatial interactions, reproduction of natural resources, protection and sharing of preserved buildings and complexes of cultural heritage, but also well balanced management of transformed area. The basis for conducted deliberations constitute studies and field studies concerning the development of urban structures, conducted for many years by the author.
\end{abstract}

Keywords: revitalization, post-harbour areas, urban space

\section{INTRODUCTION}

In New Athens Charter in an attempt to identify the basic problem of existing cities it is stated that "it is the lack of consistency, not only in a physical sense, but also in relation to the continuity in time, the lack which affects social structures and cultural differences. It is not only about maintaining the character of the urban environment, but also for the continuity of the city's identity, which is an important value, requiring the strengthening in the booming world ${ }^{\prime 2}$ [2]. It seems that this problem is specifically related to port cities. The development of these cities and the lives of their inhabitants were in an inextricable way linked with the ports and the accompanying industrial areas. Port areas mostly

\footnotetext{
${ }^{1}$ Corresponding author: Cracow University of Technology, Faculty of Architecture, Institute of Cities and Regions, Warszawska st 24, 31-155 Kraków, Poland, e-mail: nowacka.rejzner@gmail.com, tel.+ 4860882407

${ }^{2}$ New Athens Charter [2], p.5
} 
located in close proximity to downtown areas had been repeatedly transformed over the centuries. The 70 s of XX century presents a substantial change in the transport of goods by waterway and their transhipment. The established container terminals, mostly on the outskirts of cities, make the dockside of old port empty, not adapted to the new way of transhipment. In the city's spaces one created further degraded urban areas. Their existence reduces the quality of urban space, and thus the quality of life of citizens. The waterside areas, waterfront of old docks, shipyards and ports, usually with a very attractive location, are becoming areas of the world's largest ongoing revitalization projects. At abandoned by current users, degraded water areas new functions and activities are introduced. This is a complex and long process involving both activities for the entire area, resulting, among others, in the development of new functional and spatial relationships, as well as modernizing actions, renovation or restoration regarding each preserved objects or elements of the former industrial area equipment. Many of these activities are in the UK, among others, in London, Manchester, Bristol, Leeds or Cardiff. Not always presented projects and their results met with social approval and recognition. Major controversy, especially among environmentalists and naturalists, was stirred up by, e. g. Cardiff Bay project.

The basis for deliberations conducted in the article is carried out by the author scientific research on the transformation of urban downtown areas. Some of these studies concerned the transformations in the areas of port cities. Research on this group of cities, particularly related to determining the nature, extent and character of modern transformation of port areas and the impact of the results of these activities on the space of analyzed cities.

\section{CASE STUDIES}

To illustrate the problem of post-harbour areas transformation one selected two projects of completed public spaces in the Royal Docks in London. London port in its heyday was the largest port in the UK and one of the largest ports in the world. Slow disconnecting from the use of each of its parts, started in the 70s of the twentieth century, was marked in the city structure by degradation of further areas, meanwhile one made the first attempts of the ongoing process of regaining post-harbour areas for the city. The area covered by revitalization activities has been divided into four areas: Wapping, Surrey Docks, Isle Docks and Royal Docks. Actions run, for consecutive years, in particular areas made it possible to regain, with varying degrees of success, territory of the former harbour for residents. 
Currently, the most intense works are in the eastern part of London, in an area known as the Royal Docks ${ }^{3}$. This part of the London's docks largest in terms of surface $^{4}$, was commissioned at the latest ${ }^{5}$, and at the latest, because eventually only in 1983, was out of use. The program of revitalization of these areas is to create a modern, sustainable structure of residential and service with high quality public spaces and recreation areas and the construction of the airport. This is to be an area of "green investments", actually promoting sustainable urban development. Currently, part of the planned investments has already been realized $^{6}$. Among the realized investments are also public spaces that were meant to be catalysts for changes in this area: the Royal Victoria Square and Tames Barrier Park.

\subsection{Royal Victoria Square}

Royal Victoria Square ${ }^{7}$ (Fig.1) is currently attractive waterside space opened in 2000 , formerly forming part of transhipment and storage sites of the Royal Victoria Docks. Royal Victoria Docks was the first port in the London dock specially designed to accept steam ships, it was also the first where the handling equipment one used hydraulics and having direct access to the national rail network. Remains of the previous terrain features are powerful harbour cranes which form a characteristic element and promenade attraction along the river on the south side of the square, and two buildings of former tobacco warehouses ${ }^{8}$ in the northern part of the planning which after renovation perform new functions, as well as hidden from of one of these buildings, fragment of transhipment pool. An interesting solution, Inspired by harbour past of the area are metal poles, situated in the square, with the names of ships that once moored

\footnotetext{
${ }^{3}$ Royal Docks consists of three docks: Royal Albert Docks, Royal Victoria Docks, and King Georg V Docks.

${ }^{4}$ The total area of the Royal Docks is approx. 650 hectares, including a water area of approx. 81 ha by Royal Docks [4] p.47.

${ }^{5}$ Successively one put into operation Royal Victoria Dock in 1855, Royal Albert Dock in 1880, and King George V Dock in 1912.

${ }^{6}$ London City Airport opened in 1987, Regatta Centre and Olympic regatta course and the Docklands Campus of the University of East London of the area of approx. 10ha, with operating on its territory Centre of New Technologies and the ExCel exhibition centre opened in 2000, as well as The Cristal exhibition building opened in 2012 .

7 The project site of the area of 1 ha is the work of architects from offices of Patel Taylor Architects and landscape architects from the studio EDAW. In 2004 the project received Landscape Institute Design Award.

${ }^{8}$ Building magazine standing directly on the square was built in the years 1860-1865, and the second one being in the background on his right in the years 1850-1855. Both buildings were deemed historic and included in the list of historic buildings in 1998.
} 
at the quay. Eastern frontage of the square creates a wall of the building exhibition centre ExCel.

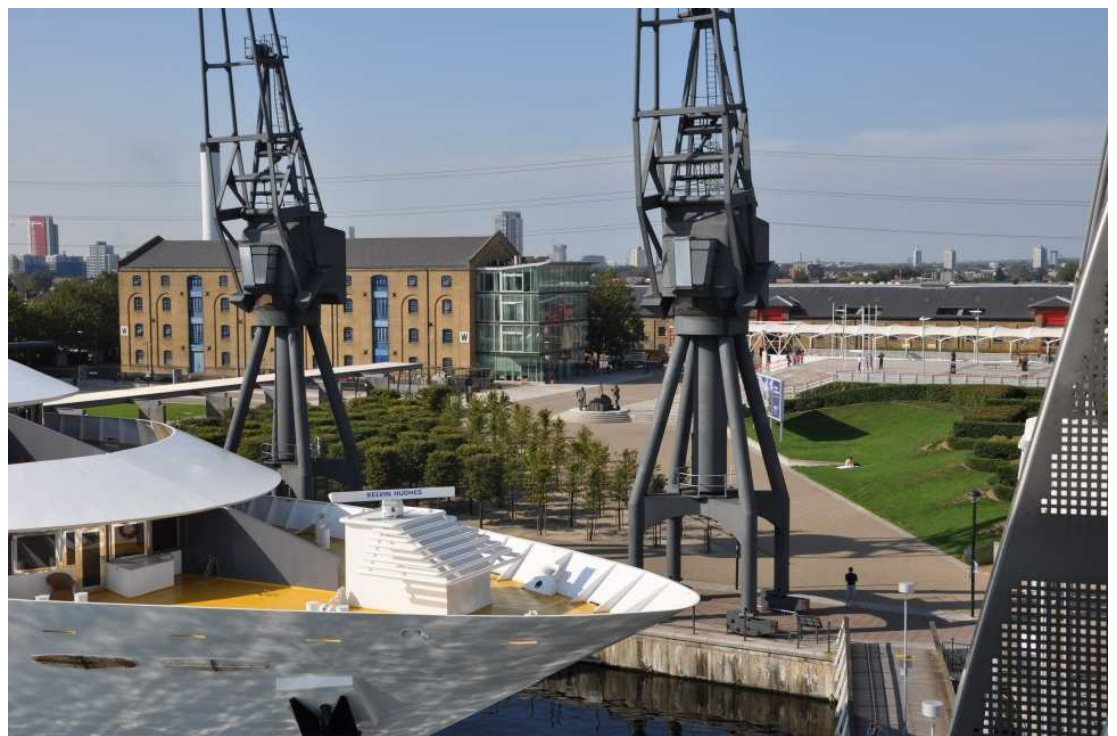

Fig. 1. Royal Victoria Square - the view from the bridge in the direction of the square (photo by author 2014)

The main entrance to the building from the centre of the square emphasize, giving it a representative character, two rows of fountains. In contrast, at the corner of the stairs leading to the terrace in front of the entrance to the building in 2009 a monument was unveiled, commemorating people working in the docks in the years 1855-1983 (Dockers Statue Royal Victoria Dock) ${ }^{9}$, being another reference to the history of the area. An interesting element in the square is also greenery. Slightly inclined plane lawn towards the river is one of the green planning, from the west and east stopped down by two steel-framed shelters under which one provided places to sit. The neighbourhood of eastern shelters is group of trees with crowns moulded in the shape of cubes. Trees are planted at equal intervals on the triangle set. However, in the immediate vicinity of the exhibition building on its western side one formed a green plane tilted toward the square with geometric forms created using topiary. In this part of the square is the entrance to the pedestrian bridge, which was opened in 1999. A significant height of the Royal Victoria Dock Bridge, resulting from the need to allow for sailing under it, makes it an excellent vantage point towards the Isle of Docks and Canary Wharf, in the opposite direction to the areas of London

\footnotetext{
${ }^{9}$ The author of the monument is sculptor Les Johanson.
} 
City Airport, and located in the area of the Albert Docks objects such as University of East London and the Regatta Centre. In June 2014 right here, on the south side of the Royal Victoria Square in the vicinity of the pedestrian bridge and building ExCel, appeared, actually moored new attractive property: Sunborn London, Luxury Yacht Hotel. Royal Victoria Square attracts different groups of users, offering to rest on the green lawns planes or to participate in numerous cultural and artistic events organized here.

\subsection{Thames Barrier Park}

Different in its spatial expression and way of developing post-harbour areas is Thames Barrier Park. The park's name comes from located in its vicinity, completed in the years 1974-1981, flood barrier on the river Thames. Park project was selected as part of the international competition in 1995. The winning design by English-French team ${ }^{10}$ was realised in the years 1997-2000. The park was established on degraded areas in the southern part of the Royal Docks in Silvertown. Due to the large soil contamination caused by previous industrial use, the area designated for the future investment needed conducting costly remediation works. Thames Barrier Park with an area of 14ha is the first river park in London. In the space of the park, the shape of which is close to the square, stands out so called "green dock", crossing the park from the north-west to south-east. This strip of land is a former dock. Originally the bottom of the dock was filled with water; this fact today is reminded by sinuously shaped yew hedges, filling the bottom of the old dock. Waves of yew hedges are separated by the specially planted, selected by colour and type, perennials and various kinds of grasses, creating unusual compositions. The dense green covers also a five-meter tall wall of the old dock, at the same time masking their protective structure. The park space, which is formed by trimmed lawns alternately with uncut meadows full of wild flowers and herbs and geometric compositions created with various species of trees, are crossed by straight path lines. Two of them lead to two pedestrian walkways, slung over the dock, from which one can admire plant compositions of "green dock" (Fig.2.), as well as enjoy extensive views of the whole park. Along both sides of the "green dock 'lead two broad promenade separated from the dock by railing. They combine, like bottom-run of the "green dock" gravel and grassy paths, two places, important in terms of composition and functionality in the park space.

\footnotetext{
${ }^{10}$ The authors of the project are: Alain Provost, Patel Taylor and Signers Groupe and engineers from Ove Aarum. The project has received numerous awards: RIBA Award 2001, Civic Trust Award 2002, AIA Award 2002 and the Millennium Marque 2000.
} 


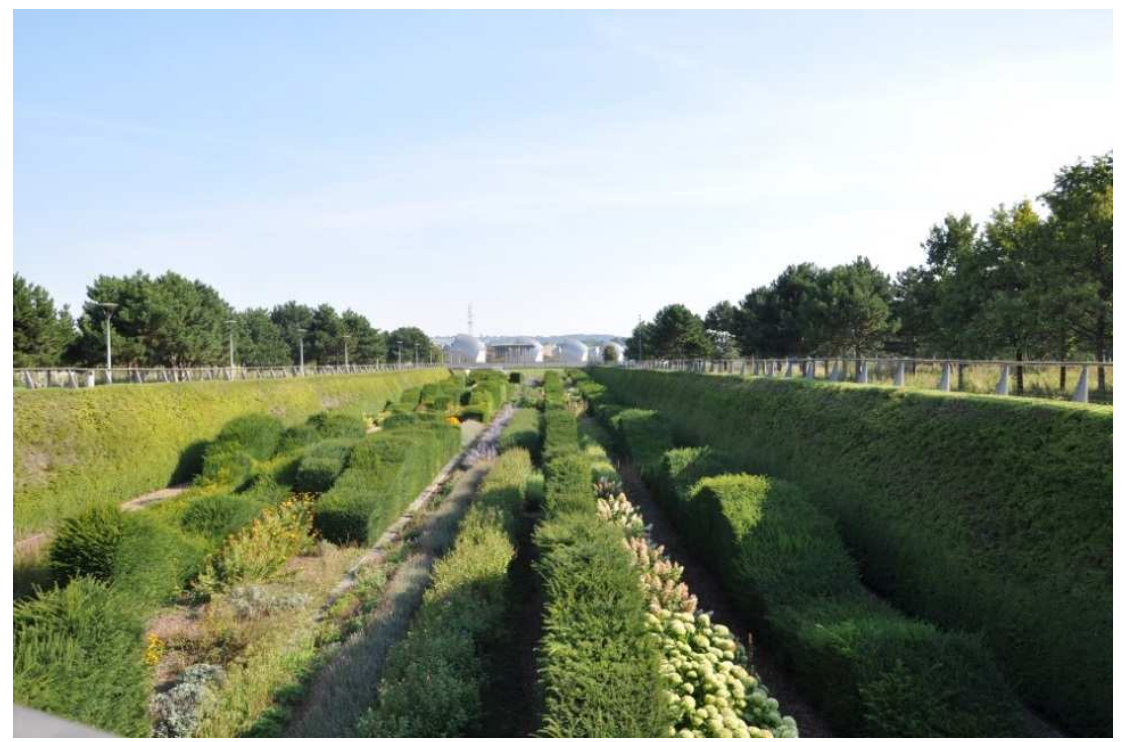

Fig. 2. Thames Barrier Park - "green dock" (photo by author, 2014)

On the north side of the park at the promenade is a raw, in the expression, pavilion by Patel Taylor, housed a cafe and information centre, with extensive wooden terrace opening onto the park. The terrace is not only a place of rest, but also a stage for artistic and cultural events taking place here. On the north side of the pavilion, in the area of the local station (Pontoon Dock) parking is located. Also on the north side of the park, but at the bottom of the "green dock", which is also street level, there is a second entrance to the park. The entrance leads to the large square plaza. The surface of the square was made of dark and light stone slabs forming stripes, whose layout overlaps the direction of the course of "green dock". A special attraction of the square is dancing fountain, whose 32 blast pipes spout water at different spatial arrangements. In contrast, on the south side of the park on a slight hill on the banks of the River Thames is located Pavilion of Remembrance. It is a place that commemorates the residents of London who died during the bombing of the city during the Second World War. Straight steel pillars support a flat roof, under which on the wooden deck are set stone benches, shaped like waves, just like hedges in the "green dock". On the eastern side of the park playground and children's sports area are located. The boundaries of the park clearly defines green wall formed from moulded, of different levels, hedges and groups of trees. On the east and west side of this green fence one creates the first buildings of housing complexes. 


\section{CONCLUSIONS}

Presented in the article two examples of new public spaces of London, carried out in post-harbour areas of the Royal Docks, are illustrations of different approaches to the role and function of retrieving lands in the city structure. Both projects were completed in the same year, though of a small surface, had a strategic importance for the reconstruction of this part of London's docks. In both cases, maintaining their water identity was considered important, albeit by different means.

In the plan of Royal Victoria Square one emphasized the historical value of the remaining elements while giving them a new meaning in the created space. To the history of the land, on which the square was built, one can also add the monument set in the park space. Additionally, the identity of the place was highlighted by used materials (wood, steel, and stone) and used light effects, emanating individual elements from the square space.

However, in the project of Thames Barrier Park one has given a new meaning to the degraded space through creative reference to symbols. The material used in this case is greenery; it is the green, chosen differently in terms of species, colours and shapes, which is arranged in stripes of various colours referring to water shimmering in the sun which in such form fills the "green dock". In the composition of the park it was considered important also to emphasize the viewing links of the park space with the surrounding areas. To the south, closing the scenic, are the silver shapes of flood control dam on the River Thames "Thames Barrier" from which the park was named. Northbound view is closed by the former grain mill "Millennium Mills". After the revitalization this building will be part of the new waterside quarter "Silvertown Quays," which is to be built in the area of the Royal Docks. Space "Silvertown Quays," through already implemented pedestrian bridge over the Royal Victoria Docks, is to be combined with the Royal Victoria Square.

Post-harbour areas of east of London gradually gain a new face, becoming a landmark of the city, while retaining its identity.

\section{REFERENCES}

1. Europejska karta planowania. Wizja Miast i Regionów - Terytoriów Europy XXI wieku. ECTP-CEU, Barcelona 2013.

2. Nowa Karta Ateńska 2003. Wizja miasta XXI wieku. Europejska Rada Urbanistów, Lizbona 2003.

3. Rewitalizacja miast w Wielkiej Brytanii. R. Guzik, Instytut Rozwoju Miast, Kraków 2009. 
4. Royal Docks. A vision for the Royal Docks prepared by the Mayor of London and Mayor of Newham. London Development Agency. London 2011.

5. Wybrane zagadnienia rewitalizacji miast, P. Lorens, J. Matrtyniuk-Pęczek, Wydawnictwo Urbanista. Gdańsk 2009.

\section{TERENY POPORTOWE - NOWA PRZESTRZEŃ MIEJSKA}

\section{Streszczenie}

Współcześnie, powszechnie zwraca się uwagę na potrzebę odzyskiwania dla różnych funkcji zdegradowanych, opuszczonych terenów miejskich. Dotyczy to także terenów w sąsiedztwie rzek i różnych zbiorników wodnych. W artykule na wybranych przykładach przedstawiono różne rozwiązania, dotyczące kształtowania zdegradowanych terenów poportowych. Podkreślono złożoność i długotrwałość prowadzonych na tych terenach działań, które obejmują zarówno: modernizację struktur budowlanych, kształtowanie nowych relacji funkcjonalno-przestrzennych, odtwarzanie zasobów przyrodniczych, ochronę i udostępnianie zachowanych obiektów i zespołów dziedzictwa kulturowego, ale także zrównoważone gospodarowanie przekształconym obszarem.

Przedstawione rozwiązania projektowe charakteryzuje różne podejście do rozwiązania problemów, różne są sytuacje przestrzenne, różne także możliwości ekonomiczne i uwarunkowania społeczne inwestycji.

Podstawę przeprowadzonych rozważań stanowią prowadzone od wielu lat przez autorkę studia i badania terenowe dotyczących kształtowania struktur miejskich.

Słowa kluczowe: rewitalizacja, tereny poportowe, przestrzeń miejska

Editor received the manuscript: 07.01.2015 $\mathrm{r}$. 